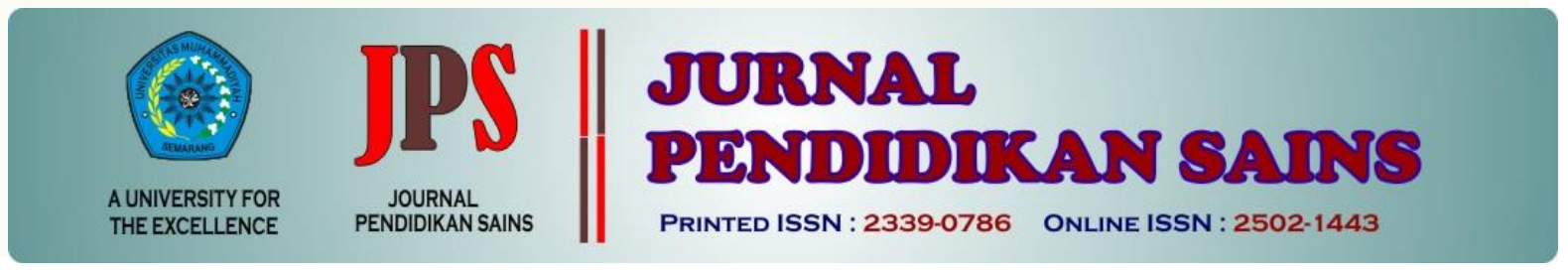

http://jurnal.unimus.ac.id/index.php/JPKIMIA

\title{
PENGEMBANGAN PERANGKAT PEMBELAJARAN IPA TERPADU BERPENDEKATAN ETNOSAINS
}

\author{
Oleh: Setyo Eko Atmojo \\ Universitas PGRI Yogyakarta
}

\begin{tabular}{|c|c|c|}
\hline Article hist & & Abstract \\
\hline Submission & : 2018-02-24 & \multirow{6}{*}{$\begin{array}{l}\text { Tujuan penelitian ini adalah mengambangkan perangkat pembelajaran } \\
\text { IPA terpadu berpendekatan Etnosains untuk meningkatkan aktivitas } \\
\text { dan hasil belajar kognitif siswa. Penelitian ini merupakan penelitian } \\
\text { pengembangan (Research and Development). Pengembangan } \\
\text { perangkat pembelajaran IPA terpadu berpendekatan etnosains terdiri } \\
\text { dari pengembangan silabus, rencana pelaksanaan pembelajaran, bahan } \\
\text { ajar, Lembar Kerja Siswa (LKS), Lembar Diskusi Siswa (LDS) dan } \\
\text { alat evaluasi. Hasil penelitian menunjukkan bahwa pembelajaran IPA } \\
\text { terpadu berpendekatan etnosains terbukti efektif mampu memperbaiki } \\
\text { kualitas pembelajaran pada aspek aktivitas dan hasil belajar kognitif } \\
\text { siswa. }\end{array}$} \\
\hline Revised & $2018-02-28$ & \\
\hline Accepted & 2018-03-02 & \\
\hline & & \\
\hline \multicolumn{2}{|l|}{ Keyword: } & \\
\hline \multicolumn{2}{|c|}{$\begin{array}{l}\text { IPA terpadu, etnosains, } \\
\text { aktivitas siswa, hasil belajar }\end{array}$} & \\
\hline
\end{tabular}

\section{Pendahuluan}

Pembelajaran selama ini cenderung hanya mengutamakan pengembangan aspek intelektual dengan buku teks pegangan guru menjadi sumber belajar utama (Lestari, A. W. 2012). Ilmu Pengetahuan Alam (IPA) merupakan mata pelajaran yang mempelajari peristiwa-peristiwa yang terjadi di alam. Pelajaran IPA di SD memuat materi tentang pengetahuanpengetahuan alam yang dekat dengan kehidupan siswa SD. Siswa diharapkan dapat mengenal dan mengetahui pengetahuan pengetahuan alam tersebut dalam kehidupan sehari-harinya (Rosyidah, A. N., Sudarmin, S. S., \& Siadi, K. K. 2013). IPA merupakan pembelajaran yang penting karena ilmunya dapat diterapkan secara langsung dalam masyarakat.

Berdasarkan observasi yang dilakukan peneliti pada awal tahun 2017 kenyataan tersebut merupakan gambaran umum yang terjadi di Kedungtuban Kabupaten Blora karena proses pendidikan formal cenderung dipandang sebagai proses pembelajaran yang terpisah dari proses akulturasi dan konteks suatu komunitas budaya. Di samping itu, banyak orang yang memandang mata pelajaran di sekolah memiliki tempat yang lebih tinggi (social prestige), dari pada tradisi budaya lokal yang dipandang tidak berarti dan rendah (discreditation) (Sardjiyo \& Pannen, P. 2005).

Saat ini banyak masyarakat Kedungtuban yang berprofesi sebagai pembuat tempe. Profesi sebagai pengrajin tempe dapat dinyatakan sebagai bagian dari budaya, karena menurut UNESCO (2002) budaya merupakan suatu cara hidup yang berkembang dan dimiliki bersama oleh sebuah kelompok orang dan diwariskan dari generasi ke generasi. Akan tetapi cara hidup atau budaya masyarakat ini kurang mendapat apresiasi positif dikalangan siswa. Kurangnya apresiasi siswa terhadap profesi tersebut dikarenakan selama ini siswa belum mengetahui bahwa dalam proses pembuatan tempe tersebut juga menggunakan prinsip-prinsip sains.

Pembelajaran berpendekatan etnosains dilandaskan pada pengakuan terhadap budaya sebagai bagian yang fundamental (mendasar dan penting) bagi pendidikan sebagai ekspresi dan komunikasi suatu gagasan dan perkembangan pengetahuan (Joseph,2010). 
Pembelajaran berbasis etnosains yang tidak memisahkan antara sains budaya dan kearifan lokal juga masyarakat dapat digunakan sebagai suatu pendekatan pembelajaran guna meningkatkan minat dan motivasi siswa terhadap sains (Rahayu, W. E., \& Sudarmin, S. 2015).

Dalam penelitian ini variabel yang akan diamati adalah aktivitas, hasil belajar siswa dan keterlaksanaan perangkat pembelajaran hasil pengembangan. Berdasarkan pada penelitian terdahulu yang dilakukan oleh (Sudarmin, Subekti, Niken dan Fibonacci, Anita. 2014) menyatakan bahwa selama ini siswa belum mengetahui bahwa dalam proses pembuatan tempe tersebut menggunakan prinsip-prinsip sains. Pembelajaran IPA berpendekatan etnosains diyakini dapat mengubah pembelajaran teacher centered menjadi student centered, menciptakan pembelajaran kontekstual dan bermakna. Pembelajaran yang menggunakan konsep budaya sebagai sumber belajar, dapat meningkatkan kemampuan siswa dalam menggunakan pengetahuan sains (Indrawati, M., \& Qosyim, A. 2017). Pembelajaran IPA berpendekatan etnosains ini mengaitkan pembelajaran IPA dengan budaya yang berkembang di masyarakat. Tahapan kegiatan pembelajaran IPA berpendekatan etnosains ini akan menuntut siswa aktif, sehingga setelah belajar siswa akan memiliki aktivitas yang lebih baik, hal tersebut akan berdampak pada tercapainya kompetensi dan hasil belajar IPA siswa yang memuaskan. Berikut ini disajikan skema kerangka berpikir secara sistematis pada Gambar 1.

1. Berkembang profesi pengrajin tempe dalam masyarakat

2. Siswa kurang menghargai tempe sebagai produk budaya

3. Siswa kurang menghargai masyarakat yang memiliki profesi sebagai pengrajin tempe

4. Pembelajaran IPA belum kontekstual dan masih beerpusat pada guru

5. Keterampilan proses sains siswa jarang dilatih sehingga kurang berkembang

6. Pengalaman belajar kurang menarik dan bermakna

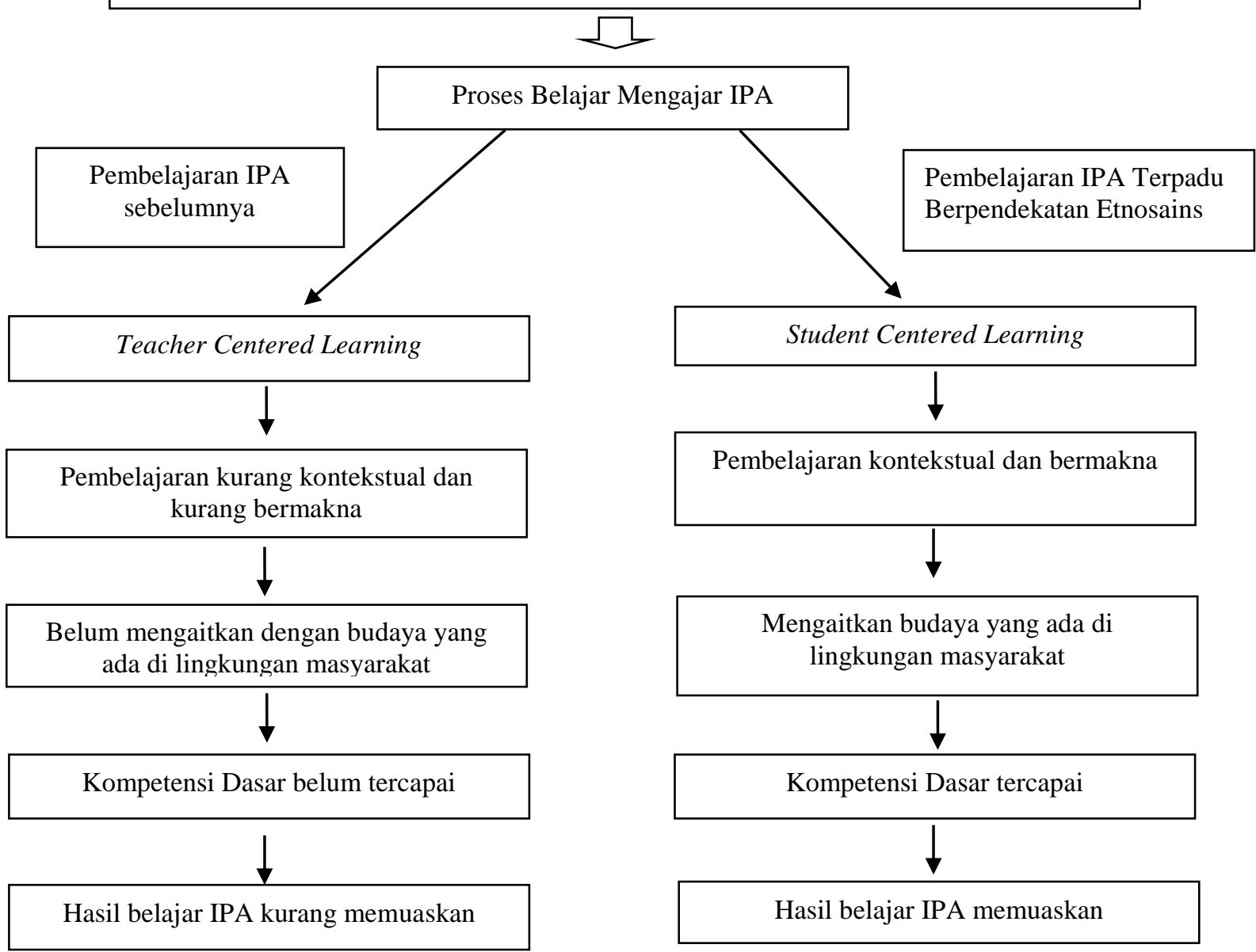

Gambar 1. Kerangka berpikir 


\section{Metode Penelitian}

Penelitian ini merupakan penelitian pengembangan (research and development). Produk yang dikembangkan adalah perangkat pembelajaran IPA terpadu berpendekatan etnosains untuk meningkatkan aktivitas dan hasil belajar siswa yang diikuti dengan pengujian mengenai keefektifan perangkat pembelajaran tersebut. Komponen perangkat pembelajaran yang dikembangkan adalah Silabus, Rencana Pelaksanaan Pembelajaran
(RPP), Bahan Ajar, Lembar Kerja Siswa (LKS), Lembar Diskusi Siswa (LDS) dan Alat Evaluasi.

Penelitian ini menggunakan pendekatan research and development (penelitian dan pengembangan) yang dikemukakan oleh (Borg and Gall, 2003). Implementasi langkah penelitian yang dikemukakan Borg and Gall dalam penelitian ini dimodifikasi menjadi tiga tahap sebagai berikut.

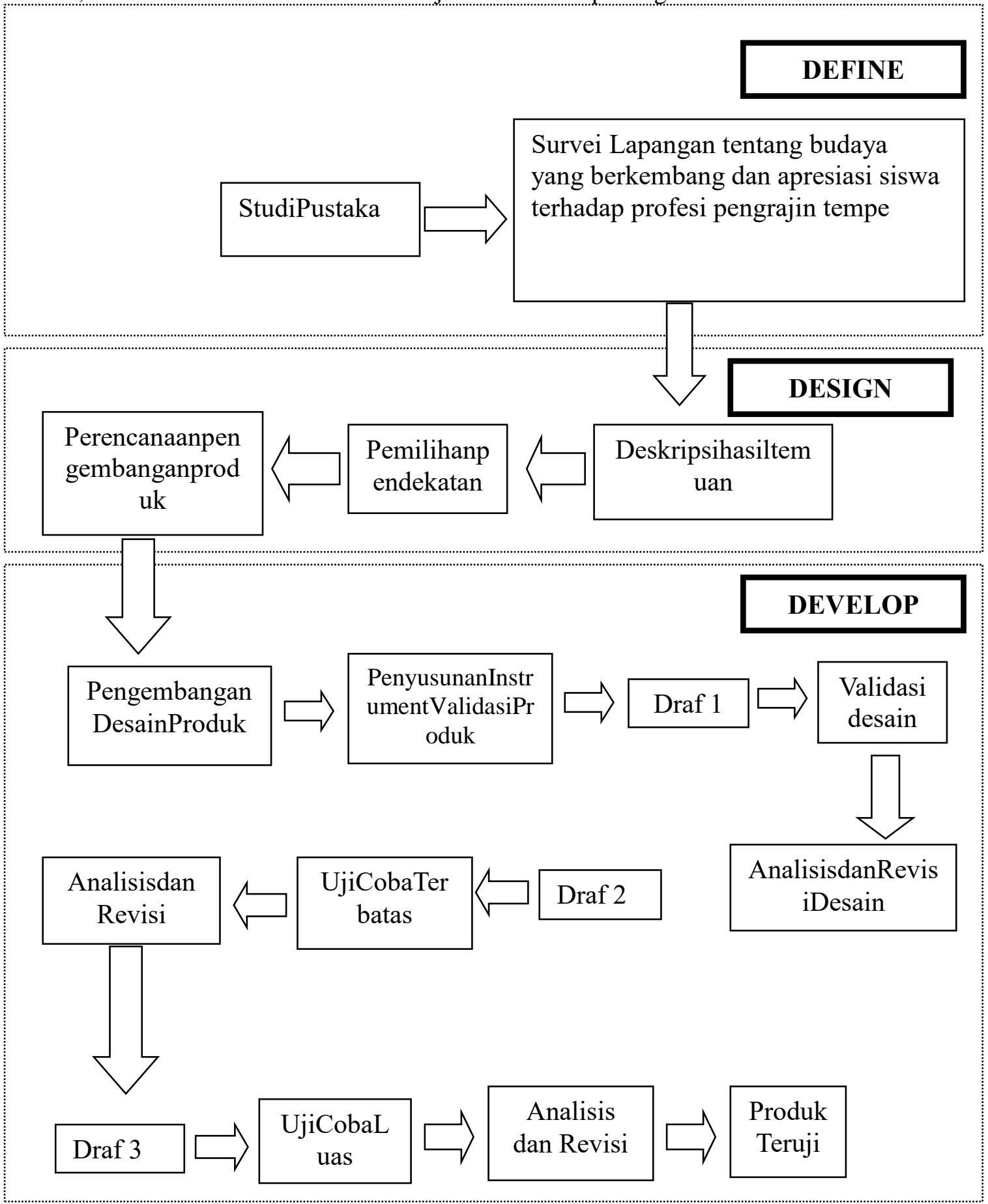

Gambar 2. Desain Penelitian dan Pengembangan 
Variabel yang diukur atau diamati dalam penelitian ini adalah kevalidan, keefektifan dan keterlaksanaan perangkat pembelajaran IPA yang dikembangkan. Aspek keefektifan yang akan diamati

Tabel 1. Jenis, Teknik, dan Instrumen Pengumpulan Data

\begin{tabular}{|c|c|c|c|c|}
\hline No & Jenis data & $\begin{array}{l}\text { Teknik } \\
\text { pengumpulan data }\end{array}$ & $\begin{array}{l}\text { Instrumen pengumpulan } \\
\text { data }\end{array}$ & Teknik analisis data \\
\hline 1 & $\begin{array}{l}\text { Validitas } \\
\text { perangkat }\end{array}$ & Angket validasi & Lembar validasi & Deskriptif persentase \\
\hline \multirow[t]{2}{*}{2} & $\begin{array}{l}\text { Keterlaksanaan } \\
\text { perangkat } \\
\text { pembelajaran }\end{array}$ & $\begin{array}{l}\text { Angket } \\
\text { keterlaksanaan } \\
\text { pembelajaran untuk } \\
\text { siswa. }\end{array}$ & $\begin{array}{l}\text { Lembar angket } \\
\text { keterlaksanaan } \\
\text { pembelajaran }\end{array}$ & Deskriptif persentase \\
\hline & & $\begin{array}{l}\text { Wawancara peneliti } \\
\text { dengan guru }\end{array}$ & Pedoman wawancara & Deskriptif \\
\hline 3 & $\begin{array}{l}\text { Hasil belajar } \\
\text { kognitif }\end{array}$ & Tes & $\begin{array}{l}\text { Lembar soal tes untuk } \\
\text { siswa }\end{array}$ & $\begin{array}{l}t \text {-test sampel releted uji } \\
\text { fihak kanan } \\
N \text { - gain }\end{array}$ \\
\hline
\end{tabular}

Penelitian ini dilakukan dalam dua tahap yaitu tahap pengembangan dan tahap implementasi. Tahap pengembangan pembelajaran berpendekatan etnosains dengan karakteristik sebagai berikut:

\section{Hasil Penelitian Dan Pembahasan}

\section{KEGIATAN AWAL}

1. Identifikasi budaya_budaya apa saja yang berkembang di masyarakat

2. Menentukan salah satu budaya yang mengandung konsep IPA, selanjutnya membahas proses yang terjadi dalam pembelajaran IPA di kelas

3. Guru menyampaikan kompetensi dasar dan tujuan pembelajaran aktivitas dan hasil belajar siswa. Adapun jenis, teknik, dan instrumen pengumpulan data dapat dilihat pada Tabel 1 berikut ini:

\section{EKSPLORASI}

(Observasi dari Perspektif Sains)

1. Guru membagi siswa kedalam kelompok kelompok (4-5 siswa) untuk melakukan observasi proses yang terdapat pada budaya tersebut dari perspektif sains asli dan ilmiah

2. Guru memfasilitasi siswa dalam melakukan observasi

3. Guru meminta siswa untuk membuat laporan hasil observasi

4. Siswa melaporkan hasil observasi dalam bentuk tertulis

\section{KONFIRMASI}

1. Guru memfasilitasi siswa untuk berkomentar, bertanya, mengklarifikasi materi pembelajaran serta melakukan refleksi

2. Guru memberikan konfirmasi terhadap hasil observasi siswa

3. Observer melakukan penilaian selama proses pembelajaran berlangsung

\section{$\downarrow$}

\section{KEGIATAN AKHIR}

1. Guru bersama siswa menyimpulkan pembelajaran

2. Guru memberikan tes akhir pembelajaran

Gambar 3. Karakteristik Pengembangan Pembelajaran Berpendekatan Etnosains 
Setelah dilakukan pengembangan perangkat perencanaan pembelajaran IPA berpendekatan pembelajaran diperoleh desain model etnosains.

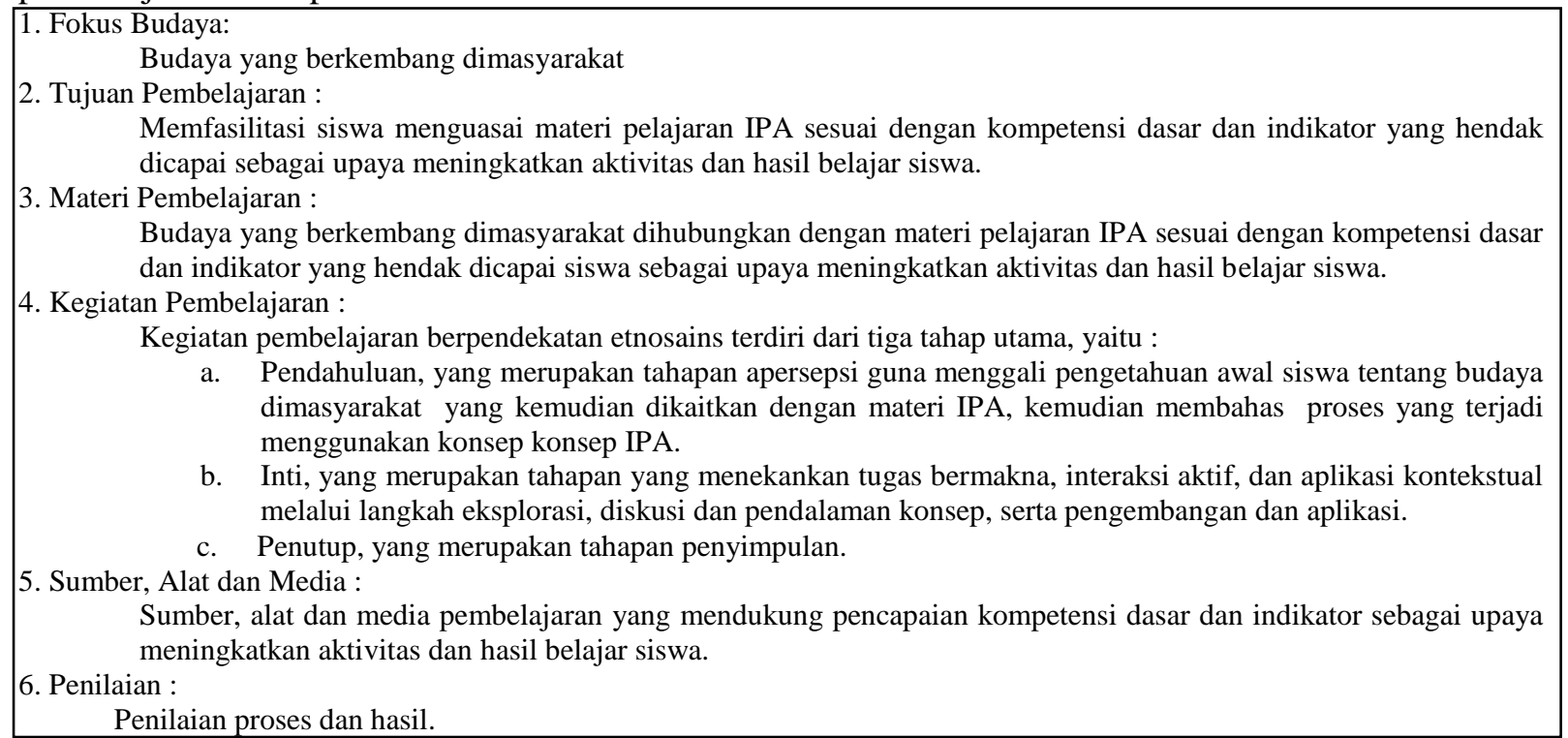

Gambar 4. Model Perencanaan Pembelajaran IPA Berpendekatan Etnosains

Untuk mengetahui pemahaman tempe menjawab pertanyaan sesuai dengan masyarakat tentang proses pembuatan tempe kemampuan dan pola pikir mereka sehingga maka dilakukan wawancara kepada masyarakat diperoleh perbandingan antara sains mayarakat pengrajin tempe mengenai proses -proses yang dengan sains ilmiah mengenai proses terjadi dalam pembuatan tempe. Pengrajin pembuatan tempe.

Tabel 2. Perbandingan Sains Mayarakat dengan Sains Ilmiah Pada Proses Pembuatan Tempe

Tahapan Sains Masyarakat Sains Ilmiah*

Perebusan biji kedelai $\quad$ Membersihkan kedelai $\quad$ Sebagai proses hidrasi yaitu agar biji kedelai menyerap air sebanyak mungkin.

Melunakkan biji kedelai supaya menyerap asam pada tahap perendaman.

Pengupasan kulit biji Menghilangkan kulit biji Agar miselium fungi dapat menembus biji

kedelai

kedelai

Perendaman biji Melarutkan kulit biji kedelai

kedelai selama proses fermentasi.

kedelai

Hidrasi biji kedelai dan membiarkan terjadinya fermentasi asam laktat agar diperoleh keasaman yang dibutuhkan untuk pertumbuhan fungi.

Fermentasi asam laktat dan pengasaman bermanfaat meningkatkan nilai gizi dan menghilangkan bakteri beracun.

Proses pencucian akhir Menghilangkan semua kotoran Menghilangkan kotoran yang dibentuk oleh bakteri asam laktat dan agar biji kedelai tidak terlalu asam.

Inokulasi Pemberian ragi untuk Inokulum dapat berupa kapang yang tumbuh fermentasi dan dikeringkan pada daun waru atau daun jati (disebut usar; digunakan secara tradisional), spora kapang tempe dalam medium tepung (terigu, beras, atau tapioka; banyak dijual di pasaran), dan kultur Rhizopus oligosporus murni (umum digunakan oleh pembuat tempe di luar Indonesia)

Pemberian lubang Agar jamur dapat tumbuh Sebagai tempat masuknya udara karena 


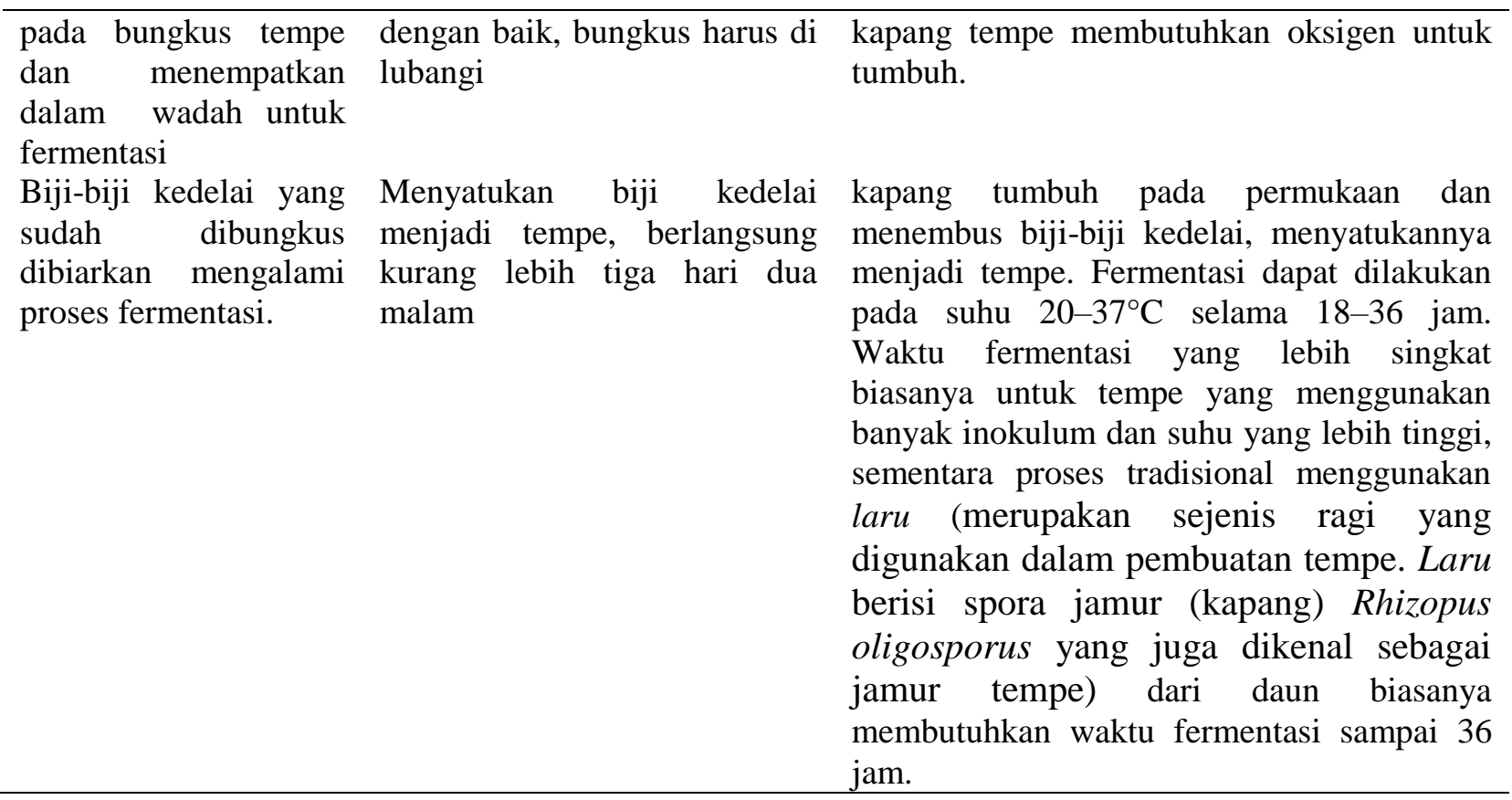

NB : *) diadaptasi dari Shurtleff, W.,Aoyagi, A. (2001)

Berdasarkan Tabel 2 diketahui bahwa masyarakat telah mengetahui proses pembuatan tempe dan dapat menjelaskan proses yang terjadi dalam pembuatan tempe sesuai dengan pengetahuan yang dimilikinya selama ini (etnosains). Walaupun masyarakat sudah dapat menjelaskan proses yang terjadi dalam pembuatan tempe sesuai pengetahuannya selama ini akan tetapi penjelasan masyarakat tersebut belum sesuai dengan penjelasan tentang proses pembuatan tempe secara ilmiah (sains ilmiah). Berdasarkan hal tersebut maka perlu dikembangkan perangkat pembelajaran
IPA berpendekatan etnosains agar siswa dapat menjelaskan proses pembuatan tempe secara ilmiah menggunakan konsep IPA yang diperoleh disekolah.

Tahap kedua adalah implementasi dari perangkat pembelajaran yang telah dikembangkan. Uraian tahap kedua adalah sebagai berikut:

Hasil implementasi perangkat pembelajaran IPA berpendekatan etnosains berdampak pada peningkatan hasil belajar siswa yang dapat dilihat pada Tabel 3 .

Tabel 3. Hasil Perhitungan Peningkatan Hasil Belajar Siswa

\begin{tabular}{lccccc}
\hline \multicolumn{1}{c}{ Kelas } & Pre Test & Post Test & Gain & N gain & Kriteria \\
\hline Uji Terbatas & 50,23 & 70,02 & 49,77 & 0,39 & Sedang \\
Eksperimen 1 & 52,56 & 71,74 & 47,44 & 0,40 & Sedang \\
Eksperimen 2 & 54,76 & 74,03 & 45,24 & 0,43 & Sedang \\
Kontrol 1 & 49,80 & 62,00 & 50,20 & 0,24 & Rendah \\
Kontrol 2 & 51,50 & 64,40 & 48,50 & 0,26 & Rendah \\
\hline
\end{tabular}

Untuk mengetahui apakah perangkat pembelajaran IPA terpadu berpendekatan etnosains dapat diimplementasikan dalam pembelajaran disebarkan angket keterlaksanaan pembelajaran kepada siswa serta melakukan wawancara kepada dua orang guru IPA di SMP Bhakti Kedungtuban. Hasil perhitungan angket keterlaksanaan pembelajaran yang diberikan pada siswa dapat dilihat pada Tabel 4 . 
Tabel 4. Hasil perhitungan angket keterlaksanaan pembelajaran

\begin{tabular}{ccccccccc}
\hline \multirow{2}{*}{ No } & Skor & \multirow{2}{*}{ Kriteria } & \multicolumn{2}{c}{ Uji Terbatas } & \multicolumn{2}{c}{ Eksperimen 1 } & \multicolumn{2}{c}{ Eksperimen 2 } \\
\cline { 3 - 8 } & & & $\sum$ siswa & $\%$ & $\sum$ siswa & $\%$ & s siswa & $\%$ \\
\hline 1 & $17-20$ & Sangat baik & 25 & 25,00 & 11 & 32,35 & 12 & 35,30 \\
2 & $13-16$ & Baik & 18 & 56,25 & 18 & 52,95 & 20 & 58,82 \\
3 & $9-12$ & Kurang Baik & 6 & 18,75 & 5 & 14,70 & 2 & 5,88 \\
4 & $5-8$ & Tidak Baik & 0 & 0 & 0 & 0 & 0 & 0 \\
& & Jumlah & 32 & 100 & 34 & 100 & 34 & 100 \\
\hline
\end{tabular}

siswa.

Berdasarkan perhitungan tersebut maka dapat diartikan bahwa perangkat pembelajaran IPA berpendekatan etnosains tepat diterapkan dikelas karena $>80 \%$ siswa memberikan tanggapan positif terhadap pembelajaran IPA berpendekatan etnosains. Sementara itu dari hasil wawancara peneliti kepada guru mata pelajaran IPA yang ada di sekolah tersebut perangkat pembelajaran berpendekatan etnosains sesuai dengan kompetensi (tujuan) yang akan dicapai dan karakteristik siswa, runtut, mudah untuk di terapkan dalam pembelajaran, praktis untuk digunakan, serta dapat meningkatkan aktivitas dan hasil belajar
Guru tidak menemui kendala yang berarti dalam menerapkan perangkat pembelajaran dikelas, kendala justru muncul dari siswa karena belum terbiasa dengan pembelajaran seperti ini. Kendala dari siswa hanya terjadi pada awal kegiatan pembelajaran selanjutnya guru mengungkapkan behwa siswa yang semula bingung sudah dapat mengikuti pembelajaran dengan baik, sehingga pembelajaran menjadi menarik dan siswa aktif dalam pembelajaran. Hasil observasi aktivitas siswa dalam pembelajaran IPA berpendekatan etnosains dapat dilihat pada Tabel 5.

Tabel 5. Hasil Perhitungan Persentase Tiap Aspek Keaktifan

\begin{tabular}{|c|c|c|c|c|c|c|c|}
\hline \multirow{2}{*}{ No } & \multirow{2}{*}{ Aspek keaktifan } & \multicolumn{2}{|c|}{ Uji Terbatas } & \multicolumn{2}{|c|}{ Eksperimen 1} & \multicolumn{2}{|c|}{ Eksperimen 2} \\
\hline & & $\sum$ siswa & $\%$ & E siswa & $\%$ & ¿ siswa & $\%$ \\
\hline 1 & $\begin{array}{l}\text { Mendengarkan ide/pendapat dari } \\
\text { kelompok. }\end{array}$ & 21 & 65,63 & 24 & 70,59 & 23 & 67,65 \\
\hline 2 & $\begin{array}{l}\text { Memberikan ide/pendapat kepada } \\
\text { kelompok. }\end{array}$ & 22 & 68,75 & 23 & 67,65 & 25 & 73,53 \\
\hline 3 & $\begin{array}{l}\text { Menanyakan kepada anggota kelompok } \\
\text { jika ada permasalahan yang tidak } \\
\text { dimengerti. }\end{array}$ & 14 & 43,75 & 14 & 41,18 & 17 & 50,00 \\
\hline 4 & $\begin{array}{l}\text { Memberikan tanggapan terhadap } \\
\text { pertanyaan dari kelompok lain. }\end{array}$ & 15 & 46,88 & 18 & 52,94 & 21 & 61,76 \\
\hline 5 & $\begin{array}{l}\text { Memberikan pertanyaan yang sesuai } \\
\text { dengan hasil presentasi diskusi kelompok } \\
\text { lain }\end{array}$ & 13 & 40,63 & 13 & 38,24 & 17 & 50,00 \\
\hline 6 & $\begin{array}{l}\text { Terlibat pada saat memperbaiki hasil } \\
\text { presentasi. }\end{array}$ & 32 & 100 & 34 & 100 & 34 & 100 \\
\hline 7 & Menanggapi pertanyaan dari guru. & 20 & 62,50 & 22 & 64,71 & 18 & 52,94 \\
\hline 8 & Menulis penjelasan guru & 32 & 100 & 34 & 100 & 34 & 100 \\
\hline 9 & Mendengarkan penjelasan guru & 32 & 100 & 34 & 100 & 34 & 100 \\
\hline 10 & $\begin{array}{l}\text { Membaca buku, LKS atau yang relevan } \\
\text { dengan pelajaran }\end{array}$ & 24 & 75,00 & 26 & 76,47 & 25 & 73,53 \\
\hline
\end{tabular}

Dalam mengembangkan perangkat pembelajaran ini, peneliti menggunakan Four D model yang terdiri atas empat tahap yaitu pendefinisian (define), perancangan (design), pengembangan (develop), namun tahap penyebaran (disseminate) tidak dilakukan. Tahap disseminate tidak dilakukan karena model pengembangan yang digunakan dalam mengembangkan perangkat pembelajaran telah

di modifikasi pada kegiatan yang terkandung dalam setiap langkah dan fase Four-D, bukan sekadar mengubah dari empat tahap menjadi tiga tahap tetapi juga dikarenakan keterbatasan waktu dan biaya penelitian. Akan tetapi perubahan model ini tidak mempengaruhi proses dan kekhasan kegiatan dalam langkah- 
langkah penelitian yang dilakukan peneliti (Rochmad, 2011).

Pendekatan etnosains merupakan strategi penciptaan lingkungan belajar dan perancangan pengalaman belajar yang mengintegrasikan budaya sebagai bagian dari proses pembelajaran IPA (Sardjiyo, 2005). Dalam penelitian ini pendekatan etnosains diimplementasikan dalam pembelajaran IPA dengan cara memasukkan budaya, khususnya profesi pengrajin tempe yang berkembang di masyarakat ke dalam pembelajaran IPA, kemudian membahas proses-proses yang terjadi pada pembuatan tempe tersebut dengan menggunakan konsepkonsep IPA.Hasil belajar merupakan perubahan perilaku yang diperoleh pembelajar setelah mengalami aktivitas belajar. Revisi Taksonomi Bloom ( Anderson L W dan Krathwohl D R. 2001) mengungkapkan tiga tujuan pengajaran yang harus dicapai dan merupakan hasil belajar yaitu: kognitif, afektif dan psikomotorik. Dalam penelitian ini hasil belajar kognitif diukur menggunakan tes, hasil belajar afektif diketahui dengan melihat apresisi siswa terhadap profesi pengrajin tempe, dan hasil belajar psikomotorik diketahui dengan melihat keterampilan proses sains siswa. Pembelajaran efektif yang dimaksud dalam penelitian pengembangan ini berkenaan dengan penilaian terhadap kualitas perangkat pembelajaran yang dikembangkan. (Nieveen, 1999) menyatakan bahwa suatu material dikatakan berkualitas jika memenuhi aspek validitas (validity). Dalam penelitian ini perangkat pembelajaran hasil pengembangan telah dinyatakn valid oleh ahli dengan tingkat kevalidan sebesar 4,12 yang berarti valid dan dapat digunakan untuk uji coba terbatas dan uji coba luas guna menguji efektivitasnya. Keefektivan perangkat pembelajran hasil pengembangan ini dilihat dari dua hal yaitu aktivitas siswa dan hasil belajar siswa.

Implementasi perangkat pembelajaran IPA berpendekatan etnosains berpengaruh terhadap hasil belajar siswa. Hasil penelitian menunjukkan adanya perbedaan hasil belajar antara siswa yang mendapatkan pembelajaran dengan pendekatan etnosains dengan siswa yang mendapatkan pembelajaran secara konvensional. Dimana siswa yang mendapatkan pembelajaran dengan pendekatan etnosains (kelas eksperimen) memiliki hasil belajar yang lebih tinggi dibandingkan dengan siswa yang mendapatkan pembelajaran konvensional (kelas kontrol). Hal ini disebabkan dalam pembelajaran IPA dengan menggunakan pendekatan etnosains siswa lebih tertarik dan antusias terhadap pembelajaran karena siswa merasa pembelajaran IPA berpendekatan etnosains lebih menyenangkan dibandingkan dengan pembelajaran konvensional. Disamping itu juga pada pembelajaran konvensional guru memegang peranan yang dominan sedangkan siswa cenderung bersikap pasif.

Peningkatan hasil belajar siswa tersebut dikarenakan adanya keterlibatan siswa selama proses pembelajaran. Hal tersebut sesuai dengan pendapat Darsono (2004) yang menyatakan bahwa salah satu prinsip belajar adalah mengalami sendiri, artinya siswa yang melakukan dengan sendiri akan memperoleh hasil belajar yang optimal. Dalam pembelajaran menggunakan perangkat pembelajaran berpendekatan etnosains siswa terlibat aktif dalam pembelajaran sehingga memiliki pemahaman yang lebih baik dari siswa yang belajar secara konvensional. Siswa yang aktif dalam kegiatan pembelajaran akan memiliki pemahaman dan hasil belajar yang lebih baik dari siswa yang hanya mendengarkan penjelasan guru dan pasif selama kegiatan pembelajaran berlangsung (Temiz-Mehmet, \& Mustafa.2006).Berdasarkan hasil observasi diketahui bahwa aktivitas siswa dalam kegiatan pembelajaran berdampak positif terhadap hasil belajar siswa, sehingga semakin tinggi aktivitas siswa dalam pembelajaran semakin tinggi pula hasil belajar yang dicapai. Terjadinya peningkatan aktivitas dan hasil belajar kognitif serta aktivitas siswa dalam pembelajaran IPA berpendekatan etnosains menunjukkan bahwa perangkat pembelajaran yang telah dikembangkan terlaksana dengan baik jika diterapkan di kelas.

\section{Simpulan dan Saran}

Pembelajaran IPA yang selama ini berlangsung di SMP Bhakti Kedungtuban Blora cenderung tidak kontekstual dan guru kurang memanfaatkan budaya yang berkembang. Perangkat pembelajaran berupa silabus, rencana pelaksanaan pembelajaran, bahan ajar, LKS, LDS dan alat evaluasi dikembangkan sesuai karakteristik pembelajaran etnosains dengan kegiatan berupa pengamatan, diskusi, presentasi dan praktikum pembuatan tempe. Proses pengembangan produk melalui tiga tahapan, yaitu tahap pertama pendifinisian meliputi studi pustaka dan survei budaya serta apresiasi siswa. Tahap kedua perancangan meliputi pemilihan pendekatan dan perencanan pengembangan produk. Tahap ketiga yaitu pengembangan perangkat pembelajaran yang terdiri dari 
penyusunan perangkat pembelajaran berpendekatan etnosains, validasi oleh tim, revisi, uji terbatas pada kelas VIIA dan uji coba luas pada kelas VIIB dan VIIC. Perangkat pembelajaran hasil pengembangan dinyatakan efektif karena terbukti mampu meningkatkan aktivitas dan hasil belajar siswa.

\section{Daftar Pustaka}

Anderson L W dan Krathwohl D R. (2001). "Revisi Taksonomi Bloom Ranah Kognitif'. (online), (http://kamriantiramli.wordpress.c om/2017/04/21/; diakses 29 Desember 2017).

Borg, W. R. \& Gall, M. D. (2003). Educational research: an introduction (7th ed.). New York: Longman, Inc.

Darsono, M. (2004). Belajardan pembelajaran. Semarang: IKIP Semarang.

Davut, H.(2008). The examination of the basic skill levels of the Students' in accordance with the perceptions of teachers, parents and students. International Journal of Instruction, 1(2), 39-56.

Hake. R.R.(2005).Will the no child left behind actpromote direct instruction of science?.AmericanJournal of Physics, 50(1),1-23.

Hobri. (2009). Metode penelitian pengembangan (developmental research)(aplikasi pada penelitian pendidikan matematika). Jember: FKIP Universitas Jember Press.

Indrawati, M., \& Qosyim, A. (2017). Keefektifan Lembar Kerja Siswa (LKS) Berbasis Etnosains pada Materi Bioteknologi untuk Melatihkan Keterampilan Proses Sains Siswa Kelas IX. E-Journal UNESA, 5(02).

Joseph, M.R. (2010). Ethnoscience and Problems of Method in the Social Scientific Study of Religion. Oxfordjournals. 39/3 : 241-249.

Lestari, A. W. (2012). Pengembangan Perangkat Pembelajaran IPA SMP Berbasis Kooperatif Tipe STAD pada Tema Fotosintesis di SMP Giki-3 Surabaya. Jurnal Pendidikan Sains Unesa, 1(1), 1-8.

National Research Council (NRC). (1996). National Science Education
Standards. Washington: National Academy Press.

Nieveen, N. (1999). "Prototype to reach product quality. Dlm. van den Akker, J.,Branch, R.M., Gustafson, K., Nieveen, N., \& Plomp, T. (pnyt.)". Design approaches and tools in educational and training. Dordrecht: Kluwer Academic Publisher.

Rahayu, W. E., \& Sudarmin, S. (2015). Pengembangan modul IPA terpadu berbasis etnosains tema energi dalam kehidupan untuk menanamkan jiwa konservasi siswa. Unnes Science Education Journal, 4(2).

Rochmad. (2011). Model Pengembangan Perangkat Pembelajaran Matematika. Jurusan Matematika FMIPA UNNES.

Rosyidah, A. N., Sudarmin, S. S., \& Siadi, K. K. (2013). Pengembangan Modul IPA Berbasis Etnosains Zat Aditif dalam Bahan Makanan untuk Kelas VIII SMP Negeri 1 Pegandon Kendal. Unnes Science Education Journal, 2(1).

Sardjiyo \& Pannen, P. (2005). Pembelajaran Berbasis Budaya: Model Inovasi Pembelajaran dan Implementasi Kurikulum Berbasis Kompetensi. Jurnal pendidikan, 6(2), 83-98.

Shurtleff, W.; Aoyagi, A. (2001), The Book of Tempeh (Edisi ke-2nd), Berkeley: Ten Speed Press.

Sudarmin, Subekti, Niken dan Fibonacci, Anita. (2014). "Model Pembelajaran Kimia berbasis Etnosains (MPKBE) untuk Mengembangkan Literasi Sains Siswa”. Prosiding Semnas Pensa VI "Peran Literasi Sains". Hal:8390.

Temiz-Mehmet, \& Mustafa. (2006). Development and validation of a multiple format test of science process skills. International Education Journal. 7(7), 10071027.

UNESCO. (2002). Universal Declaration on Cultural Diversity.Issued. International Mother Language Day. Retrieved: 2018-01-23 